\title{
Uji Efektifitas Ekstrak Kulit Petai (Parkia speciosa Hassk) Terhadap Mencit (Mus musculus) Sebagai Anti Inflamasi
}

\author{
Ilham Maulana ${ }^{\mathrm{a}, 1^{*}}$, Ajeng Kurniati $\mathbf{R}^{\mathrm{a}, 2}$, Suriani ${ }^{\mathrm{a}, 3}$ \\ ${ }^{a}$ Fakultas Farmasi, Universitas Indonesia Timur, Makassar, Sulawesi Selatan, Indonesia \\ puangillo@gmail.com* \\ *korespondensi penulis \\ INFO ARTIKEL \\ Diterima : \\ 02-07-2020 \\ Disetujui : \\ 20-07-2020

\section{Kata kunci:} \\ Ekstrak Etanol; \\ Kulit Petai; \\ Anti Inflamasi; \\ Mencit.

\section{ABSTRAK} \\ Telah dilakukan penelitian uji efektifitas ekstrak etanol kulit petai dengan \\ tujuan untuk mengetahui efek anti inflamasi dari ekstrak etanol kulit petai \\ (Parkia speciosa Hassk).Pengujian dilakukan terhadap hewan uji mencit \\ dengan melihat volume udem telapak kaki dari mencit, yang sebelumnya \\ di induksi oleh putih telur I\%. Perhitungan hasil pengujian menggunakan \\ uji analisis varians dan uji newman - keuls. Pengujian dilakukan dengan \\ membagi 5 kelompok penguian, kelompok I dengan pemberian $\mathrm{Na}$.CMC \\ I \% sebagai kelompok kontrol negatif kelompok II dengan pemberian \\ suspensi ekstrak etanol kulit petai dengan konsentrasi I \%, kelompok III \\ dengan konsentrasi 3\%, kelompok IV dengan konsentrasi 5\% dan \\ kelompok $\mathrm{V}$ dengan pemberian suspensi natrium diklofenak 0,195\%b/v \\ sebagai kelompok kontrol positif. Hasil penelitian menunjukkan bahwa \\ ekstrak etanol kulit petai dengan konsentrasi I\%, 3\%, dan 5\% memiliki \\ efek sebagai anti inflamsi. \\ Key word: \\ Ethanol Extract; \\ Petai; \\ Anti Inflammatory; \\ Mice.

\section{ABSTRACT} \\ Has conducted research Study On Effectiveness of Petai (Parkia speciosa \\ Hassk) Extract, with the aim to determine the anti -inflammatory effect \\ of the ethanol petai extract (Parkia speciosa Hassk). Testing forum mice \\ to test animals by looking at the volume of foot edema of mice, which \\ previously induced by egg white I \%. Calculations results of testing using \\ analysis of variance test and test newman - keuls. Testing is done by \\ dividing the testing group 5, group I with giving $\mathrm{Na}$. CMC I\% as a \\ negative control, group II and group administration of ethanol extract of \\ petai suspension with a concentration of $\mathrm{I} \%$, group III with a \\ concentration $3 \%$, group IV with a concentration $5 \%$ and the group $\mathrm{V}$ \\ with the provison of $0,195 \%$ diclofenac sodium suspension as the positive \\ control group. The result showed that the ethanol extract of petai with \\ concentration of $1 \%, 3 \%$, and $5 \%$ have anti - Inflamamatory effect.
}

This is an open access article under the CC-BY-SA license.

\section{Pendahuluan}

Tumbuhan dapat menjadi sumber obat bagi suatu penyakit dengan adanya metabolit sekunder yang terdapat dalam tumbuhan tersebut, dimana metabolit sekunder memiliki kemampuan sebagai aktivitas biologis. Metabolit sekunder adalah senyawa yang tidak memberi fungsi penting bagi kelangsungan hidup suatu tumbuhan tersebut. Contoh senyawa metabolit sekunder tersebut adalah flavonoid, terpenoid, alkaloid, fenol dan lain-lain.
WHO pada tahun 2008 mencatat bahwa $68 \%$ penduduk dunia menggantungkan sistem pengobatan tradisional yang melibatkan tumbuhan untuk menyembuhkan penyakit dan jumlah sediaan obat tradisisional yang di daftarkan di Badan POM akhir tahun 2006 adalah 14.217 produk.

Salah satu tanaman asli Indonesia yang dapat dimanfaatkan yaitu tanaman petai, petai umumnya dikonsumsi oleh masyrakat sebagai 
lalapan. Biji petai merupakan bagian yang umunya dikonsumsi sebagai sayuran, tetapi bagian lain seperti bunga dapat pula dikonsumsi secara mentah. Biji petai diketahui mengandung senyawa alkaloid, terpenoid, dan flavanoid, sedangkan daun petai mengandung terpenoid dan flavanoid.

Inflamasi adalah usaha tubuh untuk menonaktifkan atau merusak organisme yang menyerang, menghilangkan zat iritan, dan mengatur derajat perbaikan jaringan yang disertaiperadangan yang akan hilang jika proses penyembuhan telah lengkap. Radang atau inflamasi adalah rangkaian reaksi yang terjadi pada tempat jaringan yang mengalami cedera dan terinfeksi. Ketika proses inflamasi berlangsung, terjadi reakasi vascular dimana cairan, elemenelemen darah, sel darah putih (leukosit), dan mediator kimia berkumpul pada tempat cedera jaringan atau infeksi. Proses menetralisr dengan membasmi agen-agen yang berbahaya pada tempat cedera dan untuk mempersiapkan keadaan untuik perbaikan jaringan.

Kulit petai diketahui memilki manfaat sebagai antioksidan, antidiabetik, dan antiangiogenik. Hal ini karena di dalamnya mengandung senyawa fenol dan flavonoid dalam jumlah yang besar. Dikalangan masyarakat hanya di ketahui bahwa kulit petai yang mengandung fenol dapat digunakanuntuk anti-inflamasi luar. Berdasarkan latar belakang tersebut diatas, maka timbul permasalahan yaitu apakah ekstrak etanol kulit petai (Parkia speciosa Hassk) sebagai salah satu obat tradisional yang digunakan masyarakat berkhasiat sebagai anti inflamasi. Berdasarkan hal tersebut maka dilakukan uji efektivitas ekstrak kulit petai (Parkia speciosa Hassk) pada hewan uji mencit (Mus musculus) sebagai obat anti inflamasi. Maksud penelitian untuk mengetahui efek anti inflamasi kulit petai (Parkia speciosa Hassk) dalam bentuk ekstrak etanol dengan beberapa konsentrasi dengan menggunakan mencit sebagai hewan uji.Tujuan dari penelitian ini adalah untuk mengetahui pengaruh pemberian ekstrak kulit petai (Parkia speciosa Hassk) sebagai obat antiinlamasi pada mencit (Mus musculus).

\section{Metode}

Jenis penelitian ini adalah penelitian secara eksperimental laboratorium yakni untuk mengetahui uji efektivitas antiinflamasi ekstrak kulit petai (Parkia speciosa Hassk) yang berasal dari kota Makassar terhadap hewan uji mencit (Mus musculus) yang diinduksi dengan putih telur.

\section{Alat dan Bahan}

Batang pengaduk, corong, erlenmeyer $100 \mathrm{ml}, 250 \mathrm{ml}$, gelas ukur $50 \mathrm{ml}, 100 \mathrm{ml}$, kandang hewan, kertas saring, labu ukur $100 \mathrm{ml}$, seperangkat alat ekstraksi, spoit oral, stopwatch, sendok tanduk, timbangan analitik, pletismometer.

Air suling, mencit (Mus musculus), etanol 70\%, Kulit Petai, Natrium diklofenak tablet, Na.CMC I\%, putih telur I\%.

\section{Pengolahan Sampel}

Sampel yang digunakan adalah kulit petai yang diperoleh dari kota Makassar, Sulawesi Selatan.Kulit petai yang segar (tidak busuk) diperoleh dari pedagang petai di Makasar. Kulit petai dipotong-potong terlebih dahulu seperti dadu atau kotak-kotak kecil dan kemudian dicuci dengan air mengalir hingga bersih dan disortir yang bagus dan yang jelek atau cacat di pisahkan setelah itu kulit petai yang bagus dikeringkan dengan cara diangin-anginkan, hingga diperoleh simplisia kering, kemudian di sortir kembali dan dipasahkan kulit petai yang jelek atau cacat. Simplisia kering yang telah dipotong-potong tadidiblender sampai menjadi bubuk kasar.

\section{Pembuatan Ekstrak Kulit Petai dengan Metode Maserasi \\ Timbang bubuk kasar kulit petai} sebanyak 500 gram, kemudian dimasukan kedalam bejana maserasi kemudian ditambhkan dengan etanol sebanyak $50 \mathrm{ml}$, ditutup dan dibiarkan selama 5 hari ditempat yang terlindung cahaya sambil berulang-ulang diaduk. Setelah 5 hari, sari diserkai kedalam wadah penampung. Ekstrak yang dihasilkan disaring dan diuapkan dalam waterbath yang dipanaskan. Hasil ekstrak berupa ekstrak kental, berwarna coklat tua, dan berbau khas diambil dan diletakkan dalam wadah. Pembuatan Suspensi Na.CMC I\% b/v

Ditimbang Na.CMC sebanyak I gram, kemudian dimasukkan sedikit demi sedikit ke dalam $50 \mathrm{ml}$ air suling yang telah dipanaskan, smabil diaduk dengan menggunakan pengaduk elektrik hingga terbentuk larutan yang homogen, dicukupkan volumenya hingga $100 \mathrm{ml}$.

Pembuatan Suspensi Induksi Karagen I\%b/v Ditimbang I gram karagen lalu ditambahkan natrium klorida 0,9\% sebanyak $50 \mathrm{ml}$, dihomogenkan kemudian dicukupkan volumenya dengan suspensi $\mathrm{Na} . \mathrm{CMC}$ hingga $100 \mathrm{ml}$.

Pembuatan Suspensi Natrium diklofenak $0,0195 \% \mathrm{~b} / \mathrm{v}$ 
Suspensi Natrium Diklofenak dibuat dengan menimbang tablet natrium diklofenak yang telah digerus setara $20 \mathrm{mg}$, lalu disuspensikan dengan larutan $\mathrm{Na}$.CMC sedikit demi sedikit sambil diaduk dan dicukupkan volumenya hingga $100 \mathrm{ml}$.

Pemilihan dan Penyiapan Hewan Uji Mencit (Mus musculus)

Hewan uji yang digunakan adalah mencit jatan berumur 2-3 bulan dengan bobot badan 20-30 gram yang telah dikarantina untuk menyesuaikan diri dengan lingkungannya selama kurun waktu satu minggu. Hewan uji mencit (Mus musculus) sebanyak I5 ekor dibagi atas 5 kelompok yaitu kelompok kontrol, kelompok perlakuan dan kelompok pembanding. Kelompok perlakuan terbagi menjadi 3 kelompok. Tiap kelompok terdiri dari 3 ekor mencit (Mus musculus)

\section{Perlakuan Hewan Uji}

Sebelum perlakuan mencit dipuasakan selama 8 jam, kemudian ditimbang bobot badan awal. Kaki kiri mencit diukur volume awalnya dalam pletismometer. Masing-masing kelompok disuntikan suspensi karagen $\mathrm{I} \% \mathrm{~b} / \mathrm{v}$ sebanyak $0, \mathrm{I} \mathrm{ml}$ secara intraplantar pada telapak kaki kiri mencit, kemudian mencit dikembalikan dalam kandang pengamatan. Mencit dibagi menjadi 5 kelompok. Kelompok I sebagai kontrol yang hanya diberikan suspensi $\mathrm{Na}, \mathrm{CMC} \mathrm{I} \% \mathrm{~b} / \mathrm{v}$ per oral, kelompok II sebagai kelompok uji yang diberi ekstrak etanol kulit petai konsentrasi 5\% $\mathrm{b} / \mathrm{v}$ peroral. Kelompok III diberi ekstrak etanol kulit petai konsentrasi $10 \% \mathrm{~b} / \mathrm{v}$ peroral. Kelompok IV diberi ekstrak etanol kulit petai konsentrasi I5\% b/v peroral. Sedangkan kelompok $\mathrm{V}$ sebagai kelompok pembanding diberikan suspensi natrium diklofenak. Setelah I jam dari perlakuan volume kaki diukur dengan cara mencelupkannya kedalam alat pletismomemter untuk setiap selang waktu I jam selama 5 jam. Semua data yang diperoleh ditabulasi dan hasil setiap kelompok dirata-rata.

\section{Pengumpulan Data}

Data yang diperoleh dari hasil pengamatan dengan mengukur volume kaki mencit (Mus musculus) dan dicatat setiap interval waktu I jam 2 jam, 3 jam, 4 jam, dan 5 jam dikumpulkan dari masing-masing kelompok perlakuan.

\section{Analisis Data}

Data yang telah dikumpulkan dari hasil pengamatan ditabulasi dan dianalisis secara statistik menggunakan metode analisis of varians (Anava).

\section{Hasil dan Pembahasan}

Berdasarkan hasil penelitian efek antiinflamasi ekstrak etanol kulit petai (Parkia speciosa Hassk) terhadap mencit (Mus musculus) maka diperoleh data sebagai berikut :

Tabel I. Persentasi Penurunan Volume Udem Kaki Mencit (Mus musculus).

\begin{tabular}{cccccc}
\hline Perla & Repl & $\begin{array}{c}\text { Vol } \\
\text { kaki } \\
\text { kuan } \\
\text { ikasi }\end{array}$ & $\begin{array}{c}\text { Vol } \\
\text { kaki } \\
\text { setelah } \\
\text { induksi }\end{array}$ & $\begin{array}{c}\text { Vol. } \\
\text { Ude } \\
\text { Akhi } \\
\text { r }\end{array}$ & $\begin{array}{c}\% \\
\text { penurun } \\
\text { an udem }\end{array}$ \\
\hline Na. & I & 0,2 & 0,4 & 0,4 & $0 \%$ \\
CM & 2 & 0,2 & 0,5 & 0,5 & $0 \%$ \\
C & 3 & 0,2 & 0,4 & 0,4 & $0 \%$ \\
Rata & & 0,3 & 0,65 & 0,65 & $0 \%$ \\
-rata & & & & & \\
Ekstr & I & 0,3 & 0,4 & 0,38 & $20 \%$ \\
ak I & 2 & 0,2 & 0,5 & 0,4 & $33 \%$ \\
\% & 3 & 0,3 & 0,5 & 0,44 & $30 \%$ \\
Rata & & 0,38 & 0,74 & 0,70 & 18,52 \\
-rata & & & & & $\%$ \\
Ekstr & I & 0,3 & 0,5 & 0,4 & $50 \%$ \\
ak 3 & 2 & 0,2 & 0,4 & 0,36 & $20 \%$ \\
\% & 3 & 0,2 & 0,4 & 0,32 & $40 \%$ \\
Rata & & 0,40 & 0,77 & 0,71 & 30,26 \\
-rata & & & & & \\
Ekstr & I & 0,3 & 0,5 & 0,38 & $60 \%$ \\
ak 5 & 2 & 0,2 & 0,4 & 0,34 & $30 \%$ \\
\% & 3 & 0,2 & 0,4 & 0,32 & $40 \%$ \\
Rata & & $0,4 \mathrm{I}$ & 0,79 & $0,7 \mathrm{I}$ & 39,17 \\
-rata & & & & & $\%$ \\
Na. & $\mathrm{I}$ & 0,20 & 0,4 & 0,26 & $70 \%$ \\
Dikl & 2 & 0,2 & 0,4 & 0,24 & $80 \%$ \\
ofen & 3 & 0,2 & 0,5 & 0,28 & $73 \%$ \\
ak & & & & & \\
Rata & & $0,4 \mathrm{I}$ & 0,80 & 0,68 & 52,88 \\
-rata & & & & & \\
\hline & & & & & \\
\hline
\end{tabular}

Uji Efektifitas antiinflamasi ekstrak kulit petai (Parkia speciosa Hassk), yang telah dilakukan menggunakan metode pemberian udem buatan yang dibuat dengan menyuntikan putih telur $0,1 \mathrm{ml}$ kedalam kaki mencit secara intraplantar, kemudian diberikan ekstrak secara oral dalam beberapa konsentrasi, parameter yang diamati adalah volume udem mencit. Pemberian putih telur akan memacu prostaglandin sehingga menyebabkan inflamasi, dimana ditandai dengan adanya pembenhkakan pada kaki mencit.

Penelitian ini menggunakan natrium diklofenak sebagai pembanding dengan maksud untuk memeprlihatkan atau membandingkan bahwa ekstrak kulit petai dari beberapa 
konsentrasi apakah memberikan efek sebagai antiinflamasi, natrium diklofenak digunakan sebagai pembanding karena obat ini memiliki aktifitas dengan jalan menghambat enzim siklooksigenase sehingga pembentukan prostaglandin terhambat, selain itu natrium diklofenak juga mempunyai efek samping yang relatif kecil dari pada obat antiinflamasi yang lainnya.

Berdasarkan hasil penelitian yang telah dilakukan, bahwa pemberian Na.CMC I\% , Ekstrak kulit petai I\%, 3\%, dan 5\% b/v terjadi penurunan volume udem. Sedangkan konsentrasi $5 \% \mathrm{~b} / \mathrm{v}$ memperlihatkan efek antiinflamasi yang paling mendekati dengan efek pembanding yakni suspensi natrium diklofenak.

Hasil ini menunjukan bahwa potensi suspensi $\mathrm{Na} . \mathrm{CMC}$ I\% tidak menurunkan volume $\mathrm{A}$. udem dibandingkan dengan pemberian ekstrak kulit petai. Suspensi Na.CMC I\% dalam hal ini hanya merupakan membawa yang tidak memiliki efek farmakologis atau tidak berpengaruh dalam menurunkan volume udem kalaupun ada aktivitas dalam persentasi yang lebih kecil dikarenakan mekanisme penyembuhan yang alami dari tubuh. Berdasarkan hasil analisis data secara statistik, untuk pemberian ekstrak kulit petai dengan konsentrasi I \%, 3\%, dan $5 \%$ b/v dengan kontrol suspensi Na.CMC I\% memperlihatkan ada perbedaan yang nyata terhadap penurunan volume udem pada kaki mencit. Hubungan yang diperlihatkan bersifat linear artinya penurunan volume udem kaki mencit akan semakin meningkat dengan pertambahan konsentrasi, semakin tinggi konsentrasi yang dipakai dalam penelitian semakin besar nilai penurunan volume udem pada kaki mencit.

Hasil analisis statistik dengan menggunakan desain rancangan acak lengkap pada perlakuan selama 5 jam dengan interval waktu tiap I jam menunjukan bahwa $\mathrm{NaCMC}$ I\% sebagai control, ekstrak kulit petai I \%, 3\%, dan $5 \%$ b/v, sebagai kelompok uji dan suspense natrium diklofenak, sebagai pembanding memperlihatkan pengaruh yang nyata. Hal ini dapat dilihat pada table ANAVA dimana nilai $\mathrm{Fh}$ $>$ Ft pada taraf $\alpha=5 \%$

Pengujian lanjutan dengan uji rentang Neuman-Keuls. Dari daftar E apendiks dengan $\mathrm{V}=\mathrm{I0}$ dan $\boldsymbol{\alpha}=0,05$, menunjukan perbedaan yang signifikan dari setiap kelompok dengan kelompok lainnya dan dari data yang diperoleh bahwa kelompok dengan konsentrasi yang paling tinggilah dalam hal ini $5 \%$ yang paling memberikan efek yang mendekati efek pembanding dari natrium diklofenak disbanding dengan kelompok pemberian ekstrak I \% dan 3 $\% \mathrm{~b} / \mathrm{v}$.

\section{Simpulan dan Saran}

Pemberian Ekstrak Kulit Petai (Parkia speciosa Hassk) pada mencit jantan (Mus musculus) yang di induksi putih telur I\% dan dengan pengamatan selama 5 jam dalam waktu interval tiap I jam dengan konsentrasi ekstrak I $\%$, $3 \%$ dan $5 \%$ b/v menunjukan penurunan volume udem pada kaki mencit. Ekstrak Kulit Petai (Parkia speciosa Hassk) dengan konsentrasi $5 \%$ b/v menurunkan Volume udem pada kaki mencit lebih besar dibandingkan dengan ekstrak konsentrasi I \%, dan $3 \%$ b/v.

Disarankan untuk penelitian selanjutnya untuk meningkatkan konsentrasi dari ekstrak kulit petai untuk mendapatkan efek yang seoptimal dengan pemberian natrium diklofenak serta dilakukan uji toksikologi dari kulit petai dengan rentang yang lebih luas sehingga bias didapatkan dosis yang optimal dari kulit petai sebagai efek antiinflamasi.

\section{Daftar Pustaka}

Dewoto. (2007). Pengembangan Obat Tradisional Indonesia Menjadi Fitofarmaka. Jakarta: FKUI. Maj Kedokt Indonesia. Volum:57, Nomor;7 Juli.

Ganiswara, S.G. (2009). Farmakologi dan Terapi. Edisi V. Bagian Farmakologi FK UI. Jakarta.

Harvey, R.A. Champe, P.C. (200I). Farmakologi Ulasan Bergambar. Edisi II. Alin Bahasa Azwar Agoes. Penerbit Widia Media. Jakarta.

Karim A. Azrina A. (2012). Review: Fruits Pod Extracts as a Source of Nutraceuticals anf Pharmaceuticals.

Kelompok Kerja Ilmiah. (1993). Penapisan Farmakologi, pengujian fitokimia, dan Pengujian klinik, Pedoman Pengujian dan Pengembangan Fitofarmaka, Pengembangan dan Pemanfaatan Obat Bahan Alam. Yayasan Pengembangan Obat Bahan Alam Phyto Medika: Jakarta.

Malole, M.B.M. dan Pramono, S.S.U. (I989). Penggunaan Hewan-Hewan Percobaan di Laboratorium. Penelaah Maduki Pertadireja. Departemen Pendidikan Tinggi Pusat antara Universitas 
Bioteknologi. Institut Pertanian Bogor: Bogor.

Saifudin. A, Rahayu, V. And Teruna, H.Y. (20II). Standarisasi Bahan Obat Alam. Yogyakarta: Graha Ilmu

Tjay H.T. dan Kirana, R. (2007). Obat obat Penting, Khasiat, Penggunaan dan EfekEfek Sampingnya. Edisi 6. PT. Elex Media Komputerindo. Kelompok Gramedia. Jakarta.

Vickery, M. And Vickery, B. (1980). Secondary Plant Metabolism. London: The Maccmillan Press LTD. 